\title{
Presidential politics of constitutional amendment in Francophone Africa: The case of Senegal
}

\author{
ŁUKASZ JAKUBIAK* (1)
}

Institute of Political Science and International Relations, Jagiellonian University, Cracow, Poland

\section{ORIGINAL RESEARCH PAPER}

Received: May 7, 2020 • Revised manuscript received: August 17, 2021 • Accepted: March 25, 2021

Published online: January 13, 2022

(c) 2021 Akadémiai Kiadó, Budapest

\begin{abstract}
The paper is devoted to the role of the head of state in initiating and implementing constitutional reforms in Senegal. This country can legitimately be regarded as one of the few examples of a relatively successful democratization process in Africa, as evidenced, among other things, by the lack of military coups leading to the loss of power by civilian governments, as well as by two democratic transfers of power (in 2000-2001 and 2012), after which the main opposition parties gained the presidency and the majority of parliamentary seats. Both these fundamental political transformations generated important constitutional changes (for example, the adoption of the current Constitution of 2001, or the constitutional modifications of 2016 and 2019) that have influenced, to a greater or lesser extent, the position of the presidency in Senegalese systems of government. The author analyses their significance for the functioning of contemporary political institutions in the broader context set by the politics of constitutional amendment which was conducted by previous presidents of this country. The main goal of the paper is to examine to what extent the constitutional modifications introduced before and after the adoption of the 2001 Constitution were designed to contribute to the beginning or consolidation of pro-democratic trends, and to what extent they were created to strengthen the position of an incumbent president himself, leading to a political imbalance and regress in the democratization process. The author argues that the constitutional modifications adopted over the years have often gone in two opposite directions, influencing the efficiency and durability of Senegalese institutional structures.
\end{abstract}

\section{KEYWORDS}

constitutional amendments, president, system of government, term limits, political opposition, Senegal

\footnotetext{
*Corresponding author. E-mail: lukasz.jakubiak@uj.edu.pl
} 


\section{INTRODUCTORY REMARKS}

Depending on the type of political regime, the presidential politics of constitutional amendment may bring different results from the perspective of incumbent heads of state. Much depends on the strength and effective influence of institutional or partisan veto players operating in a particular political regime. As George Tsebelis points out, the former should be defined as 'individual or collective veto players specified by the constitution', whereas the latter are 'generated inside institutional veto players by the political game'. ${ }^{1}$ The weakness of such political actors may result in the disruption of mechanisms which ensure the balance between authorities, or significantly impede the formation of such a balance (in the case of authoritarian states which have not yet entered the phase of democratization). The lack of a well-established democratic order creates convenient grounds for particular activity by those political actors who play leading roles within concrete political systems. In case of Francophone African countries these are presidents who operate under the conditions of presidential or semi-presidential systems of government, and may exert an immense influence on the space available for inter-party competition. Such factors most often impede, and sometimes even completely prevent, the democratic takeover of power by opposition parties. This, in turn, means that in political practice, only military coups or violent mass street protest i.e. actions which do not meet the standards of democracy - may effectively impose some limits on heads of state. ${ }^{2}$ As practice shows, the removal of presidents by force, even through so-called promissory coups, which are ultimately intended to result in democratic elections conducted on the initiative of military leaders, neither improve the quality of political institutions nor increase the level of democracy. ${ }^{3}$

A strong position for presidents within presidential or semi-presidential systems of government and the dominance of a presidential formation over opposition parties at the parliamentary level (if, indeed, the latter are present in the legislature) mean that the impact of heads of state on shaping public policies does not face any serious restrictions. This also applies to influencing the content of constitutional regulations, which are usually created or modified to meet the expectations of presidents. Important constitutional provisions that prejudge, or at least co-shape (directly or indirectly), the presidents' position within the framework of broader institutional structures are primarily those regarding systems of government, presidential succession and the possibility of multiple re-election, as well as the status of political parties (including the parliamentary opposition). Constitutional provisions in force in these areas at various periods of the functioning of a particular political system can be treated - as long as they can have a noticeable impact on political actors' conduct - as a hallmark of the pro-democratic or anti-democratic properties of a given constitutional order. This may be exemplified, first and foremost, by the introduction or removal of restrictions regarding presidential terms of office. ${ }^{4}$ It

\footnotetext{
${ }^{1}$ Tsebelis (2002) 79.

${ }^{2}$ As in the case of Burkina Faso, where President Blaise Compaoré was forced to resign in 2014 after 27 years in office because of mass social resistance to his attempts to preserve the presidential mandate. See Chouli (2015) 325-33 link 4.

${ }^{3}$ Bermeo (2016) 8-10.

${ }^{4}$ According to Wiebusch and Murray, presidential term limits may be defined as 'explicit temporal restrictions on the ability of a president to hold the top executive office'. Hence, such restrictions result solely from appropriate legal provisions concerning the length of the presidential mandate, and do not refer to other factors that are not of a temporal character (such as eligibility critaria). See Wiebusch and Murray (2019) 133.
} 
can be added that such constitutional changes seem to be particularly important in those countries where democracy is not well-established, or in those where authoritarianism is relatively weak and remains supplemented by elements of pluralistic political competition. Modifications regarding admissible re-election may then be a clear signal for opposition formations, shaping their own political strategies. Depending on the content of such amendments, the above-mentioned activities can be oriented either to winning presidential or parliamentary elections within the existing political arrangements or to seeking to gain power by bypassing formally binding procedures. ${ }^{5}$

Considering the countries that previously belonged to the French colonial empire, it can be said that the one in which the dynamics of constitutional changes in the three areas mentioned above can be observed is the Republic of Senegal. Compared to other former French colonies, this West African state is characterized by political stability and the ability to function with a democratic system that assumes periodic turnovers of power. This distinguishes Senegal from many other Francophone countries of Sub-Saharan Africa, in particular those that were (or may still be) placed among so-called failed or fragile states (for example, Ivory Coast and the Central African Republic). This can be explained by the fact that during almost sixty years of independent statehood Senegal has never experienced a military coup or other type of political disorder destabilizing the functioning of the entire constitutional system. Relatively early, in the mid-1970s, legal activities of certain political parties began to be allowed, which alleviated the effects of a typical one-party model without elements of any inter-party competition. The very process of democratization in this country was extended in time and proceeded gradually. This does not mean, however, that from today's perspective its effects can be considered optimal. Senegalese democracy still leaves a lot to be desired. This was revealed in particular during Abdoulaye Wade's presidency which occurred, somehow paradoxically, after the first democratic transfer of power conducted in 2000-2001. The slightly authoritarian practice of exercising power then became noticeable. This was exemplified by the political events of 2007 when parties belonging to the anti-government opposition boycotted parliamentary elections in protest against anti-democratic actions taken by the presidential political camp. ${ }^{6}$ All in all, the fact that Senegalese democracy is not of high quality, which brings this political system closer and closer to the category of so-called hybrid regimes, certainly affects the content and dynamics of constitutional reforms.

When it comes to the mechanisms of the constitutional system of government, Senegal consistently adopts a model of very strong presidential power. Most importantly, the head of state reserves the capacity to initiate and effectively implement constitutional reforms. From a formal perspective, one of the features of the appropriate procedures applied in Francophone African countries is the cooperation between the legislature and the executive, which could already be seen in the constitutions adopted after these countries gained independence from France. ${ }^{7}$ Although the role of the president in the process of changing the constitution was not provided for in the Senegalese 1960 Constitution, ${ }^{8}$ this act was in force for almost three years,

\footnotetext{
${ }^{5}$ Baturo and Elgie (2019) 10.

${ }^{6}$ Heyl (2019) 339.

${ }^{7}$ Prouzet (1979) 284-85.

${ }^{8}$ Loi n ${ }^{59-003 ~ d u ~} 24$ janvier 1959 (Constitution de la République du Sénégal) link 11.
} 
and relatively quickly the procedure taken from the French Constitution of 1958 appeared (with some slight differences). In the 1963 Constitution $^{9}$ (based on a presidential system of government and a unicameral legislature), which - despite many subsequent modifications - was in force until 2001, the procedure for its amendment was as follows: the initiative to change the constitution could be taken by the president of the Republic and by members of parliament (the National Assembly). The latter body had to pass such an amendment, which could result in a referendum for its approval. A popular vote was not obligatory. The head of state could decide to subject the modification exclusively to the National Assembly which had to adopt it by a majority of three-fifths of all deputies who made up this body. After the establishment of a bicameral parliament, senators could also exercise the right to initiate constitutional bills. The 2001 Constitution ${ }^{10}$ did not change much of the procedure described above. Bearing in mind that a relatively balanced semi-presidential system was then adopted, it should be noted that the prime minister was given the right to propose constitutional changes to the president. Due to the transition from semi-presidentialism to presidentialism (in 2019), the institution of prime minister no longer exists, which may possibly have some impact on initiating constitutional amendments.

A common feature of the above-mentioned procedures is, firstly, the decisive role of the head of state and, secondly, the necessity to have constitutional changes adopted by the parliament. Neither the participation of the nation itself through the referendum, nor the contribution of the prime minister (in the case of semi-presidentialism) is of primary importance. At first glance, it seems that, in line with the aforementioned concept presented by Tsebelis, the role of veto players could potentially be played by parliaments themselves. However, taking into account political realities makes it necessary to adopt a different view. The exceptionally strong position of presidential parties (the parties backing incumbent presidents) means that in practice the legislative power cannot act as a balancing factor holding back heads of state from implementing their own strategies in the field of constitutional amendments. As political practice demonstrates, in Francophone African countries, initiatives to change constitutions undertaken by parliaments occur rarely, if at all. ${ }^{11}$ The same conclusions can be drawn from the practice of modifying Senegalese constitutional provisions. ${ }^{12}$ This can be regarded as one of the phenomena contributing to the high dynamics and frequency of constitutional changes that have been carried out since independence in 1960. During this period, three constitutions have been in force in Senegal. With the exception of the 1960 Constitution, all the legal acts were modified on different occasions. It should be stressed that these changes were carried out regardless of who was the incumbent head of state (Léopold Sédar Senghor - 1960-1980, Abdou Diouf - 1980-

\footnotetext{
${ }^{9}$ Loi n ${ }^{\circ}$ 63-22 du 7 mars 1963 portant révision de la Constitution de la République du Sénégal link 14.

${ }^{10}$ Loi n ${ }^{\circ} 2001-03$ du 22 janvier 2001 portant Constitution link 10.

${ }^{11}$ Bininga (2019) 65-67. This can be regarded as a property of president-dominated political systems where, due to the pro-presidential structure of the parliament, the requirement of a qualified majority for the effective implementation of the politics of constitutional reforms is not a significant obstacle. This distinguishes such countries from well-established democracies, where the adoption of constitutional changes requires the cooperation of various political forces. If this is the case - as Anna Fruhstorfer and Michael Hein point out - 'constitutional politics provides an ideal field to link institutional characteristics and institutional interests with political outcomes'. See Fruhstorfer and Hein (2021) 2.

${ }^{12}$ Fall (2020) 58-59.
} 
2000, Abdoulaye Wade - 2000-2012 or Macky Sall - since 2012) and regardless of the existence of an authoritarian or democratic political order.

The purpose of the article is not to review all constitutional modifications carried out in the last six decades, but only those that were of strategic importance (relating to the very structure of the system of government; regulating presidential succession and terms of office; creating the constitutional foundations for the activities of political parties, including primarily those belonging to the opposition). These three areas are closely related with each other and require a comprehensive analysis from the perspective of the politics of constitutional changes. It may be argued that the mere adoption of the 2001 Constitution, which is applied in conditions of relatively fair political competition, has not fundamentally affected the presidential politics of constitutional amendment. As in the earlier period, the changes seem to go in different directions, contributing to the protection or deterioration of democratic constitutional values, such as the separation and balance of powers within a system of government, mechanisms of presidential succession, or multi-party political competition. Their analysis will make it possible to reveal basic tendencies in this area, as well as to assess them from the perspective of the coherence of the activities undertaken.

The basic research question of this paper is thus whether the politics of constitutional amendment in Senegal have effectively contributed to the consolidation of pro-democratic tendencies, or increased institutional imbalances and undermined the democratization process. It may also turn out that, regardless of the authoritarian and democratic features of a particular system (in any case without powerful institutional veto players that could actively influence constitutional modifications), the politics of constitutional reforms implemented over six decades has been, generally speaking rather chaotic, and still devoid of a clearly visible vector of changes. Nevertheless, the question arises whether this view is correct in relation to each of the above-mentioned areas of constitutional modifications. The point is that the level of consistency of the politics of constitutional amendment (such consistency should be perceived as a process to implement changes aimed, in the short or long term, towards a single coherent goal, for example deepening the pluralization of political life ${ }^{13}$ ) may not be the same in all the three fields. This primary assumption clearly requires verification. This should be tested with reference to the authoritarian and democratic phases of the Senegalese political system. It seems that the lack of strong institutional veto players who would be able to stop, or at least to hinder the said politics, means that in this respect the differences between unconsolidated democracies and hybrid or even authoritarian regimes are rather blurred.

\footnotetext{
${ }^{13}$ Hence, it is not the consistency understood as the internal integrity of the constitution in which particular provisions are properly composed with each other. For more on consistency concerning constitutional regulations see: Fruhstorfer (2019) 1028-46. The coherence of the politics of constitutional amendment referred to in this article is not the coherence of constitutional designs as such, but the coherence of actions undertaken by various political actors, usually over a longer time scale (during several terms of office of various presidents). They may, for example, consistently strive to adopt constitutional provisions to strengthen parliament in order to restore the balance of powers, or undertake actions to reject the contribution of their predecessors to the text of the constitution. In short, political leaders can deepen (by going in the same direction) the constitutional changes introduced by their predecessors, maintain the status quo, or reject these changes in order to restore regulations that were in place previously. Of course, this kind of activity can significantly affect the coherence of the constitution itself. Constitutions that are subject to frequent and hasty changes can be much less internally consistent.
} 
The findings presented may contribute to further research on the role of powerful political actors in the area of shaping constitutional provisions in order to satisfy their own narrowly defined interests. It seems that such arrangements can be particularly valuable in the case of states that are neither unequivocally democratic nor unequivocally authoritarian, thus oscillating, like Senegal, between more or less defective democracies and hybrid regimes. ${ }^{14}$ The political dynamics resulting from such properties of the regime may affect, at least to some extent, the politics of constitutional amendment, including, above all, the actions of heads of state striving to strengthen their own political position by way of deliberate constitutional modifications or to introduce changes favourable to their political camps.

\section{CONSTITUTIONAL REFORMS CONCERNING THE SYSTEM OF GOVERNMENT (THE TRANSITION FROM PRESIDENTIALISM TO SEMI- PRESIDENTIALISM AND VICE VERSA)}

A system of government as such should be understood as an organizational form of government in a broad sense of the word, which means that this notion cannot be reduced to the executive branch itself but extends to the relationship between the executive and legislative. Such a broadly-defined government may be organized in various ways, and parliamentarism, presidentialism and semi-presidentialism are its typical embodiments. ${ }^{15}$ As regards differences between particular regimes, José Antonio Cheibub argues that the fundamental division comes down to the question of whether cabinets may be removed exclusively by parliaments, exclusively by presidents or by each of the two bodies independently. ${ }^{16}$

Differences between presidential and parliamentary systems are relatively easily to identify (under presidentialism, the executive is politically independent of the parliament in the sense that the latter cannot dismiss it, and under parliamentarism, the head of state has no direct political influence over the cabinet, which depends solely on the parliamentary majority), but semi-presidentialism still raises certain controversies. Hence, various definitions have been presented (by Maurice Duverger, Giovanni Sartori, Robert Elgie and other scholars). As for the political responsibility of ministers, it is often assumed that there may be a single responsibility

\footnotetext{
${ }^{14}$ Before 2019 Senegal was classified not as a hybrid regime, not to mention an authoritarian system, but as a flawed democracy (according to the Democracy Index, presented periodically by the Economist Intelligence Unit, flawed democracies score between 6 and 8 on a ten-point scale). In the 2018 country ranking Senegal ranks $73 \mathrm{rd}$ on the list of classified countries in the world - with a score of 6.15 points. Of the five determinants to assess the quality of democracy, the most points were given to pluralism and the electoral process - 7.5. See Democracy Index (2018) link 5. However, in the 2019 Democracy Index Senegal started to be considered a hybrid regime ( $82^{\text {nd }}$ place in the world with 5.81points). See Democracy Index (2019) link 6. This suggests that the pro-democratic properties of the Senegalese political system are slowly disappearing, and some features that are typical of authoritarian regimes are gaining importance. All this, however, does not automatically rule out the ability to carry out transfers of power quite democratically and without using force. It is worth mentioning that despite the drop in the ranking, Senegal is still listed in the highest place among all Sub-Saharan African countries which were former French colonies.

${ }^{15}$ Müller (2017) 137.

${ }^{16}$ Cheibub (2007) 34. There are also some common features. For example, in both parliamentarism and semi-presidentialism, there are bicephalous executives, which means that heads of state are more or less separated from governments led by prime ministers.
} 
(only to the parliament) or a double responsibility (also to the president). Hence, semi-presidential systems are quite diverse. According to Matthew S. Shugart and John M. Carey, such regimes may appear in two basic forms - as the so-called premier-presidentialism ${ }^{17}$ (which is closer to parliamentarism) or president-parliamentarism ${ }^{18}$ (which is a typical mixed system with a doubly responsible cabinet). ${ }^{19}$ Moreover, when it comes to stabilizing or destabilizing democracy, semi-presidential systems are not judged in a conclusive fashion. On the one hand, they provide a chance to avoid the accumulation of power by one political individual or group, but on the other hand, they can cause uncontrolled conflicts between the main political actors (the phenomenon of cohabitation within the executive branch). ${ }^{20}$

After independence in 1960, the Senegalese systems of government were based on all three of the aforementioned models: parliamentary, semi-presidential and presidential regimes. Parliamentarism was introduced in the 1960 Constitution, which was a continuation, to a greater extent, of the one adopted in $1959 .^{21}$ Systems of government in both legal acts were based on the same general ideas. ${ }^{22}$ The noticeable differences between them related to more detailed matters. As regards the 1960 Constitution, one of its important components was the election of the head of state by a special electoral college similar to that applied at the beginning of the Fifth French Republic. In the light of the Senegalese constitutional provisions, presidential powers were based on the idea of political arbitration, and the task of determining and conducting state policies belonged formally to the prime minister. It was only a year later that an amendment was adopted $^{23}$ enabling the president to dissolve parliament, provided that two successive ministerial crises occurred. While taking into account the parliamentary responsibility of the government, the institutional construction described above resulted in the implementation of a relatively typical parliamentary system.

However, the first two Senegalese presidents - Senghor and Diouf - decided to introduce further significant changes regarding the system of government, which caused it to oscillate between presidentialism and semi-presidentialism. A deep conflict between the then incumbent president (Léopold Sédar Senghor) and the prime minister (Mamadou Dia), which occurred at the end of $1962,{ }^{24}$ was an impulse for a definite strengthening of the presidency by introducing a

\footnotetext{
${ }^{17}$ Shugart and Carey (1992) 23-24.

${ }^{18}$ Shugart and Carey (1992) 24-25.

${ }^{19}$ Elgie considers these two institutional constructions to be the basic subtypes of semi-presidentialism. Although the latter is defined very broadly in his concept, it is not difficult to determine which country adopts this regime and which does not. He argues that it is sufficient for the cabinet to be politically responsible to parliament and for the president to be elected by universal suffrage. This also explains why it seems justified to distinguish specific sub-types of semipresidentialism. See Elgie (2011) 27-30.

${ }^{20}$ For more see Elgie (2011) 10-17.

${ }^{21}$ Loi n ${ }^{\circ}$ 60-045 A.N. du 26 août 1960 (Loi sénégalaise portant révision de la Constitution de la République du Sénégal) link 12. Obtaining independence, which was followed by the adoption of a new constitution, meant that Senegal, like the vast majority of former French colonies, lost the status of an autonomous republic within the French Community (Communauté française) created in 1958.

${ }^{22}$ Fall (2009) 32-42.

${ }^{23}$ Loi n ${ }^{\circ}$ 61-63 du 12 novembre 1961 portant révision de la Constitution link 13.

${ }^{24}$ Zuccarelli (1988) 86-90; Lavroff (1966) 47-55.
} 
pure presidential regime (the 1963 Constitution $^{25}$ ). It was the conflict between political leaders that was, from Senghor's point of view, an argument for establishing a unified executive power. ${ }^{26}$ The post of prime minister was thus abolished, and ministers started to be subordinated directly and solely to the president as the exclusive leader of the executive branch. The head of state was to be elected by popular vote, and the dissolution of parliament was no longer possible. The same applied to a parliamentary vote of no confidence in the government. The lack of both institutions can be treated as a typical structure of a presidential system, which, however, was disturbed by restoring, in a limited form, the possibility of dissolving the legislature (1967). ${ }^{27}$ In this way, some components of parliamentarism started to be incorporated into the structure of Senegalese presidentialism, which made the constitutional regime quite original. ${ }^{28}$

The presidential system did not prove to be permanent and in 1970 the institutional framework was replaced by a strongly presidentialized version of semi-presidentialism (i.e. a president-parliamentary formula with a particularly powerful head of state). ${ }^{29}$ This led to the restoration of the prime minister who, however, was subordinated - not only in political realities but also according to the letter of the constitution - primarily to the head of state. It is worth mentioning that the transition to semi-presidentialism did not only occur in Senegal, but was a broader tendency occurring at that time in some other former French colonies. ${ }^{30}$ At the end of Senghor's last term of office, the semi-presidential system was retained but this did not lead to its consolidation as a relatively permanent form of the organization of public authorities. Presidentialism returned in $1983,{ }^{31}$ in the first years of Diouf s presidency. Just as twenty years earlier, the post of prime minister was abolished and the head of state formally became the sole wielder of executive power. Its concentration in the hands of the head of state occurred under the pretext of the need to overcome an economic crisis. ${ }^{32}$ Nevertheless, the same Senegalese president decided to restore semi-presidentialism in $1991 .{ }^{33}$ At that time, democratization processes emerged in Francophone African countries, generating more advanced changes within constitutional systems of government. In the light of newly adopted or heavily revised constitutions, the executive became two-headed and more internally balanced. Pure presidential systems with

\footnotetext{
${ }^{25}$ This was the beginning of pure presidentialism in Senegal. It is worth noting, however, that in some other Francophone African countries such a system of government was adopted immediately after gaining independence in 1960, as may be exemplified by the case of Ivory Coast. For more on the latter country see: Alexander (1963) 291-311.

${ }^{26}$ Gellar (2005) 45.

${ }^{27}$ Loi n ${ }^{\circ}$ 67-32 du 20 juin 1967 portant révision constitutionnelle link 15. According to modified constitutional provisions, the parliament could be dissolved only after the end of the third year of parliamentary term. What is more, the presidential term of office was then extended to five years.

${ }^{28}$ Fall (2009) 64-65.

${ }^{29}$ Loi $n^{\circ} 70-15$ du 26 février 1970 portant révision de la Constitution link 16. The establishment of the institution of prime minister was then quite a typical phenomenon in those former French colonies where in the 1960s the constitutions had previously provided for presidential systems. For more on this topic see: Fall (2008) 15-16.

${ }^{30}$ Fall (2008) 15-16.

${ }^{31}$ Loi $\mathrm{n}^{\circ} 83-55 \mathrm{du} 1^{\mathrm{er}}$ mai 1983 portant révision de la Constitution link 21. As it turned out, Senegalese semi-presidentialism, even in its strongly presidentialized version which reduced the government to the role of the executor of policies set by the head of state, survived only thirteen years.

${ }^{32}$ Sidibé (2006) 48.

${ }^{33}$ Loi n ${ }^{\circ} 91-25$ du 5 avril 1991 portant révision de la Constitution link 22.
} 
unified executives were then exceptions to the rule. ${ }^{34}$ In many former French colonies, so-called national conferences (conférences nationales) were convened to create new constitutional orders (Benin is an example of such a country), ${ }^{35}$ but this was not the case in Senegal. The earlier partial inclusion of some opposition parties into parliamentary competition contributed to the fact that - unlike in many other countries of Francophone Africa - no deep pro-democratic constitutional reforms were carried out in the early 1990s. Hence, the constitution adopted in the first years of Senegalese independent statehood could be preserved, although after introducing some significant modifications indicated above. As for the legal structure of the system of government, in the following ten years (until the adoption of the current constitution) the act of 1963 was not subject to further amendments.

The entry into force of the Constitution of 22 January $2001^{36}$ did not mean a radical change in the system of government, which was still based on the semi-presidential construction. It was balanced by strengthening the government with a second component of executive power, next to the head of state. However, this did not change the fact that a stronger version of semi-presidentialism was then preserved in Senegal. As noted above, its constitutive feature is the principle of the cabinet's political responsibility not only to the legislature, but also to the president. What is more, such a rule must be explicitly expressed in constitutional provisions (the so-called president-parliamentarism as one of two basic forms of semi-presidentialism). As a consequence, the acquisition of power by a long-term main opposition party (the Senegalese Democratic Party led by Abdoulaye Wade) did not mean a significant weakening of the constitutional status of the president within the system of government. On the other hand, the politics of constitutional amendment pursued by politicians outside the Socialist Party of Senegal, which remained in power during the presidency of Senghor and Diouf, did not assume, at least until recently, the strengthening of presidential power by eliminating a two-headed executive branch. The attempt to introduce a pure presidential system was not made by President Wade, although during his twelve-year presidency the head of state was accused by the opposition of violating various democratic standards of governance. Hence, the system of government adopted in the 2001 Constitution could be assessed as relatively stable. Institutional changes carried out after the first power alternation did not concern its basic structure, but involved secondary institutions, although the latter could indirectly affect the real scope of presidential competences. For example, in 2012 a newly elected President Sall decided to abolish the Senate, in which the opposition to the head of state held a majority of seats. ${ }^{37}$ It is worth noting that the 2019 constitutional reform initiated by Macky Sall immediately after winning the presidential election (the National Assembly adopted the reform a few weeks after the president was sworn in ${ }^{38}$ ) was the first attempt to introduce a presidential system since the democratic

\footnotetext{
${ }^{34}$ Fall (2008) 16-20.

${ }^{35}$ Manning (1998) 190-201.

${ }^{36}$ The reason for the adoption of the 2001 Constitution was the transfer of power resulting from the governing party's candidate's loss in the 2000 presidential election. The newly elected President Wade announced a reform of the existing semi-presidential system of government, which aimed at weakening the position of the president. These changes, however, did not prove to be far-reaching.

${ }^{37}$ Soares (2012) link 25; Le Sénégal supprime son Sénat (2012) link 7.

${ }^{38}$ Au Sénégal, le président Macky Sall va supprimer le poste de Premier ministre (2019) link 2; Au Sénégal, le Parlement adopte la réforme constitutionnelle (2019) link 1.
} 
transfer of power of 2000-2001. In this case, some efforts to consolidate the power of the head of state at the start of the second presidential term may be noticed but the final results of such actions are still unclear. ${ }^{39}$

\section{CONSTITUTIONAL REFORMS AFFECTING PRESIDENTIAL TERMS AND SUCCESSION (THE PRESERVATION OF POWER WITHIN THE SAME POLITICAL CAMP)}

Amendments of constitutional provisions relating to presidential succession appeared for the first time in the last phase of Senghor's presidency. Senegal operated at that time as a limited multi-party system, and the loss of power as a result of the democratic transfer of power did not pose a real threat to the ruling camp. However, President Senghor tried to steer the presidential succession process through the politics of constitutional modifications. The post of prime minister, which was restored in 1970 in connection with the establishment of semi-presidentialism, served that purpose. Pursuant to the constitutional regulation introduced in $1976,{ }^{40}$ it was the prime minister who was to take up the presidential mandate and hold it until the end of the full presidential term in the event of the death or resignation of the incumbent head of state. As noted above, in a strong version of semi-presidentialism it is the president who can decide freely on the selection of the prime minister, who bears political responsibility not only to the legislature but also to the head of state. Bearing in mind the effects of the constitutional changes of 1970 and 1976, it can be said that President Senghor had full and direct influence on who would become a new president after his decision to step down before the end of his term. Using the constitutional mechanisms created by the president himself, Senghor resigned from the presidency in $1980 .{ }^{41}$ Such a decision resulted in a fully controlled presidential succession within the ruling camp. It is worth mentioning that Senghor's successor, Abdou Diouf, did not have democratic legitimacy during the first years of his term of office, as universal presidential elections were not held until $1983 .{ }^{42}$

In the case of President Diouf, the approaching end of his second term caused the constitution to be amended to remove the term limit applicable in previous decades (it was introduced by the constitutional reform of 1970, repealed in 1976 and re-introduced in 1991 on the wave of the democratization processes in various Francophone African countries). The removal of this provision two years before the planned presidential election (held in 2000) dispersed any doubts about the possibility to run for the presidency for the fourth time in a row (Diouf was elected

\footnotetext{
${ }^{39}$ However, it should be borne in mind that formal constitutional amendments that change the whole system of government may also refer to some more specific issues, such as the length of the presidential mandate and the admissibility of re-election. There is then the opportunity to make modifications allowing the head of state to be re-elected one more time, even if the regulations in force at the beginning of the presidency banned it. If this is the case, a comprehensive constitutional revision introducing a new system of government could become only an excuse to extend the presidential power beyond pre-determined time limits.

${ }^{40}$ Loi $\mathrm{n}^{\circ} 76-27$ du 6 avril 1976 portant révision constitutionnelle link 18.

${ }^{41}$ Sy (2009) 123-25; Zuccarelli (1988) 157-59.

${ }^{42}$ Sy (2009) $158-59$.
} 
president in 1983, 1988 and 1993). The ban on holding the third presidential mandate was restored in the 2001 Constitution, ${ }^{43}$ which was one of the consequences of Diouf s electoral failure and the democratic transfer of power. It is worth mentioning that the term limit was also lifted during Senghor's third presidential term (elected in 1963, 1968 and 1973), but ultimately he did not run, as indicated above, for another presidential mandate. Presidential terms of office seemed to be inscribed into the Senegalese 1963 Constitution only when such regulations did not prevent the aspirations of major political actors. Until 2000, both presidents implemented their own political strategies without any significant restrictions that might result from legal bans, or from the strength of the political formations conducting anti-government actions in order to take over the power.

Another aspect of institutional changes at the constitutional level, which were associated with efforts to maintain power within one political camp, was an unsuccessful attempt to regulate presidential succession by using the office of vice president. The latter institution was established in 2009 by President Wade. ${ }^{44}$ A year earlier, the presidential term was extended from five to seven years, ${ }^{45}$ which was one of many modifications to the length of the presidential mandate that had been adopted since the 1960s. ${ }^{46}$ Pursuant to the constitutional regulations of that time, the head of state (now elected for a relatively long period of time) could be assisted by a vice president, but in practice this post remained vacant. After two years, the incumbent president announced a constitutional change that would have modified the role of the vice presidency. The same applied to the requirement to obtain an absolute majority of votes in the first round of presidential elections (according to the draft regulations, 25\% of votes would be enough to win a presidential mandate in the first round). As for the vice presidency, it was expected that it would be entrusted to the President's son, Karim Wade. In turn, lowering the requirement to win a presidential mandate would have significantly increased the chances of reelection because opposition parties were quite fragmented at that time. ${ }^{47}$ In both cases, President Wade's political position would be considerably strengthened. Mass street protests fuelled by the opposition under the slogan 'Don't touch my constitution' forced the head of state to give up the announced constitutional reform. ${ }^{48}$ However, the actions taken by Wade to amend the 2001 Constitution solely to facilitate presidential succession was the most serious crisis related to the presidential politics of constitutional amendment since the democratic transfer of power at the beginning of the 21st century. It is worth mentioning that after the 2012 presidential election in which the then incumbent head of state lost his fight for a third presidential term, the post of vice president was abolished. It should be stressed that - as ruled by the Senegalese Constitutional Council at the end of Wade's second term - the then incumbent head of state could run for the third time because no term limits applied when Wade had been elected president for the first time in $2000 .^{49}$ As indicated above, they were lifted in 1998 by President Diouf, and re-

\footnotetext{
${ }^{43}$ Fall (2017) 113-14.

${ }^{44}$ Loi constitutionnelle $n^{\circ}$ 2009-22 du 19 juin 2009 instituant un poste de Vice-président de la République link 9.

${ }^{45}$ Loi constitutionnelle $\mathrm{n}^{\circ} 2008-66$ du 21 octobre 2008 link 8.

${ }^{46}$ Fall (2017) 108-109.

${ }^{47}$ McConnell (2011) link 22; Ba and O’Reilly (2011) link 3.

${ }^{48}$ Mueller (2018) 20; Wade drops contested electoral reform (2011) link 26; Demarest (2015) link 4.

${ }^{49}$ Senegal's president can run for third term, court rules (2012) link 24.
} 
introduced in the 2001 Constitution. It may be argued that in this way Wade's predecessor contributed to such an effect although his intention was to extend his own presidency by winning another presidential mandate in 2000. Nevertheless, Wade's electoral defeat in 2012 meant that the lifting of the presidential term limit in 1998 did not have far-reaching consequences for the Senegalese political scene. Wade's renewed candidacy after two presidential terms was a political strategy strongly contested by the opposition, which saw it as a violation of the 2001 Constitution and called for anti-presidential street protests. ${ }^{50}$

The extensive constitutional reform of 2016, which was initiated by President Sall, introduced a provision according to which no one can hold more than two consecutive presidential mandates. ${ }^{51}$ Such a constitutional regulation seems to follow the provision included in the constitution of the Fifth French Republic in 2008. It needs to be emphasized that there were no constitutional provisions with such a wording in the earlier stages of the development of Senegalese constitutionalism. However, it is too early now to assess the actual significance of the above-mentioned restriction.

\section{CONSTITUTIONAL REFORMS REGARDING POLITICAL PLURALISM (THE ACTIVITY OF POLITICAL PARTIES, THE PARTY SYSTEM AND POLITICAL PARTICIPATION)}

Compared to other Francophone African states, Senegal started on the road leading to the pluralization of political life relatively early. This was reflected at the constitutional level in two amendments adopted in $1976^{52}$ and $1978 .{ }^{53}$ The presidential camp decided to introduce a specific structure of a limited multi-party system, allowing the activity of three and then four political formations. What is more, each party was supposed to represent a different ideological trend. In order to consolidate a four-party system in 1978, these four currents (socialist, liberal, conservative and communist) were precisely determined in the text of the constitution. The governing party declared itself as socialist. In the second half of the 1970s this political formation changed its name to the Socialist Party of Senegal. The then partial democratization of the Senegalese political system was caused by President Senghor's political aspirations. He wanted his party to become a member of the Socialist International. This in turn required the legalization of opposition groups, including the Senegalese Democratic Party led by Abdoulaye Wade. ${ }^{54}$ The latter party became a permanent participant in Senegalese political life, but until 2001 the governing formation was able to retain an overwhelming majority of seats in the National Assembly. However, the constant presence of the Senegalese Democratic Party at the parliamentary level meant that the effects of the constitutional changes adopted in 1970s proved to be permanent.

\footnotetext{
${ }^{50}$ Court rules (2012) link 24.

${ }^{51}$ Fall (2017) 113-15.

${ }^{52}$ Loi n ${ }^{\circ} 76-01$ du 19 mars 1976 portant révision de la Constitution link 17.

${ }^{53}$ Loi n ${ }^{\circ} 78-60$ du 28 décembre 1978 modifiant la Constitution link 19.

${ }^{54}$ For more on Senghor's approach to the legalization of the PDS, see Desouches (1983) 27-30.
} 
The politics of constitutional amendment aimed at democratizing political life was continued by President Diouf, who in 1981, i.e. at the very beginning of his presidency (even before obtaining popular legitimacy in the 1983 presidential election), decided to fully democratize the party system by lifting restrictions on the number of legalized parties and their ideological profiles. ${ }^{55}$ This constitutional change quickly brought visible political effects in the form of the legalization of a large number of new political formations. ${ }^{56}$ In any case, the Senegalese Democratic Party - the first political organization from outside the presidential camp, admitted to legal activity as early as $1974^{57}$ - retained its status as the main opposition formation. Nevertheless, the entire party system of that time started to be clearly fragmented (which, however, was not visible at the parliamentary level, where the presidential party still dominated). It can even be assumed that, paradoxically, this was the goal of the pluralization of political life. The ruling elite feared the ability of the then opposition to become a real threat to the Socialist Party. Such a scenario would have been realistic if Wade had turned out to be able to unite different opposition formations against the government. ${ }^{58}$ Fewer political parties functioning legally would probably have made this task much easier.

When the political formation headed by Abdoulaye Wade gained power in 2000-2001 by first winning the presidency and then obtaining a vast majority in the National Assembly (which caused the marginalization of the Socialist Party), further consolidation of the democratic order could be expected. The practice of exercising power proved, however, that the long-time Senegalese opposition leader did not show full readiness to comply with the rules of completely democratic and fair political competition. In particular, some actions were taken aimed at weakening the opposition parties. ${ }^{59}$ Nevertheless, the negative phenomena which occurred in the political practice were counterbalanced by the introduction of constitutional regulations aimed at strengthening political pluralism. Such provisions were contained in the original version of the 2001 Constitution and referred directly to the status of the parliamentary opposition. ${ }^{60}$ Another step in this direction was to modify the constitution to formalize the role of the opposition leader as well as to guarantee candidates from outside political parties the opportunity to participate in elections. The latter modifications were initiated by President Macky Sall and adopted in $2016 .{ }^{61}$

\footnotetext{
${ }^{55}$ Loi n ${ }^{\circ}$ 81-16 du 6 mai 1981 portant révision constitutionnelle link 19. As a consequence, many new political parties soon began to be formed in Senegal but due to the constant dominance of the governing party, they were not able to obtain a relevant political position. For more on this topic, see Nzouankeu (1984) 33-37.

${ }^{56}$ Nzouankeu (1984) 33-37.

${ }^{57}$ Desouches (1983) 15-27.

${ }^{58}$ Heyl (2019) 345.

${ }^{59}$ Diop (2013) 432-38; Osei (2012) 183-84.

${ }^{60}$ In modern constitutions, including those in fully democratic states, this is still not a common phenomenon. These legal acts usually refer to political parties as such, thus without recognizing their formal status as the anti-government opposition.

${ }^{61}$ Fall (2017) 95-101.
} 


\section{FINAL REMARKS AND CONCLUSIONS}

An analysis of the constitutional changes that have been made in the above-mentioned areas over the course of the almost sixty years of Senegal's independent statehood leads to several basic conclusions. They should be supplemented by some reservations regarding the political context of the process of introducing constitutional amendments. First of all, it deserves to be noted that even after the introduction of a licensed multi-party system (restricted to three or four parties that could function legally) in the late 1970s, the governing formation overshadowed other political groups, including the main part of the anti-government opposition - the Senegalese Democratic Party. However, the latter formation turned out to be able to gain only a small number of parliamentary seats. As a result, the 1976 constitutional amendment concerning presidential succession could not be aimed at preventing the governing party from losing power. It was only intended to manage internal competition within the presidential camp. This scenario was already carried out in 1980 because Abdou Diouf became the new president without the need for universal elections. The fully democratic transfer of power at the beginning of the $21^{\text {st }}$ century proved that the political contexts of the constitutional changes were not the same as in the first four decades of independent Senegal. Under the new conditions, the emergence of a strong opposition party or coalition of parties could become a serious threat to the incumbent head of state. This was confirmed by Macky Sall's victory in the 2012 presidential election. Although Sall initially belonged to the Senegalese Democratic Party, being an important figure of the presidential camp in the first years of Wade's presidency, he managed - thanks to his political emancipation and the creation of a strong camp composed of the parties belonging to the opposition to the head of state - to win the presidency in 2012. Secondly, regardless of the specific political circumstances, parliamentary configurations created in legislative elections are always strongly affected by the existing political profile of the presidency. This in turn creates the formula of so-called majoritarian presidentialism (présidentialisme majoritaire) known from the Fifth Republic of France. Hence, the head of state politically dominates both the government and the parliamentary majority formed by a presidential formation. It is worth noting that political parties with the majority of seats in the National Assembly traditionally back incumbent presidents (the only exception was the period between the presidential elections in 2000 and the parliamentary elections in 2001; in 2000, the newly elected president Wade did not have the constitutional competence to dissolve parliament to speed up parliamentary elections). This is true for the Senegalese Progressive Union (transformed in 1976 into the Socialist Party of Senegal) under Presidents Senghor and Diouf, the Senegalese Democratic Party under President Wade and the Alliance for the Republic under President Sall. The practice of the long-lasting cohabitation of conflicted leaders holding executive power is thus alien to Senegalese mechanisms of exercising power. Such an effect should be attributed not only to the political composition of parliament but also to the exceptional constitutional position of the head of state. The latter factor undoubtedly distinguishes most semi-presidential regimes in former French colonies (mainly president-parliamentary sub-types) from that adopted in France (a premierpresidential version). ${ }^{62}$ Consequently, there are no political barriers that could effectively influence the politics of a constitutional amendment conducted in accordance with expectations

${ }^{62}$ Conac (2007) 88. 
formulated by the head of state. As an unsuccessful attempt to regulate presidential succession within the family of President Wade has shown, it may be that only mass social protests will prove to be an obstacle to presidential political ambitions that must be reckoned with. However, such protests have nothing to do with the constitutional procedure for amending the constitution, in which institutional veto players practically do not exist.

The conclusions drawn from the analysis of the aforementioned constitutional changes are as follows:

1. One of the most important areas of profound constitutional reforms is the system of government. Not counting the adoption of the 1960 Constitution, significant modifications in this field have been initiated seven times by all presidents, including the current one (Macky Sall). He decided to present a proposal to reintroduce, after almost three decades of semipresidentialism, a presidential system, and thus to undermine the institutional framework created following the 2000-2001 democratic transfer of power. This, however, does not change the fact that regardless of the system of government (presidential or semi-presidential) the constitutional position of the head of state has never been significantly weakened. Given the constant dominance of presidential parties at the parliamentary level, the structure of the system of government does not seem to matter, because according to the letter of the constitution ministers always remain subordinate to the president. In such a situation there is no real chance of the emergence of cohabitation which could be a threat to presidential power (as shown in the example of Niger in the years 1995-1996 ${ }^{63}$ ). ${ }^{64}$ Nevertheless, in the fourdecades preceding the first democratic transfer of power initiatives to change the structure of the system of government were much more frequent. Constitutional amendments of this type were adopted on average every ten years. Both President Senghor and President Diouf decided to adopt presidentialism first $(1963,1983)$, and then - in the second phase of their presidencies - semi-presidentialism (1970, 1991). Only Abdoulaye Wade and Macky Sall decided not to change the existing system of government in the first years of their presidencies. For this reason, the political regime established in 2001, implemented under conditions of the transfer of power and the unrestricted competition of political forces, seem to show greater stability. However, the transition from semi-presidentialism to presidentialism in 2019 may produce a change in this state of affairs.

2. In Senegal, there have been various attempts to influence the process of transferring presidential power after the term of office of a given head of state. The presidential politics of constitutional amendment have served as a tool to achieve such effects. This strategy was implemented by President Senghor when the goal was to transfer presidential power within the governing camp (the constitutional amendment of 1976). The second initiative to amend the constitution to regulate presidential succession was aimed at maintaining power by the presidential formation as well as at preventing the opposition from gaining the presidency (the failed attempt to introduce, in 2011, a relevant constitutional amendment). To achieve this goal, President Wade wanted to use the post of vice president (established two years

\footnotetext{
${ }^{63}$ For more on this topic see: Moestrup (2007) 112-15.

${ }^{64}$ Incidentally, long-term cohabitation may result, above all, from a weaker version of semi-presidentialism (premierpresidentialism), in which the head of state does not have the constitutional tools to force the government to resign easily. This has never been the case in Senegal.
} 
earlier). This would have meant the implementation of a scenario which is mainly possible in presidential regimes because the office of vice president exists primarily in countries adopting this model. No similar attempt to consolidate the power of one political camp occurred at the end of Diouf's presidency. In the latter case, however, the ban on the second re-election was lifted (constitutional amendment of 1998). Nevertheless, after forty years in power the governing camp proved unable to win the 2000 presidential election (President Diouf lost to Wade in the second round of voting). As it has turned out, each of the three former presidents undertook more or less advanced initiatives to modify the 1963 Constitution to transfer or maintain power. Only Senghor's strategy brought the intended effect. As for Macky Sall, it is too early to assess the current presidency in this respect. Nevertheless, it should be borne in mind that in 2019, after the first seven-year term, President Sall was elected once again, this time for five years. This sets a new perspective for the further strengthening of presidential power through the politics of constitutional amendments. In any case, it is difficult to say that there has been a uniform approach to the constitutional regulation of presidential succession, although presidents have tried to implement quite similar strategies (for example, restrictions on the number of terms of office were usually introduced when, due to the presidency stage, they could not be a serious obstacle to running for re-election; otherwise they were lifted).

3. It seems that the constitutional changes relating to political parties and, in general, political pluralism, have remained fairly consistent. Each of the four presidents have undertaken constitutional initiatives gradually aimed at democratizing political life by allowing or strengthening, at least according to the letter of the constitution, the status of parties from outside the governing camp (the introduction of a three-party system and a four-party system in the 1970s, the lifting of barriers to the activities of political parties and full multiparty competition in the early 1980s, the recognition in the constitution and strengthening of the parliamentary opposition). This should not automatically lead to the conclusion that the practice of political competition was equally pro-democratic. On the other hand, however, the departure from the restrictive one-party system in the second half of the 1970s as well as the reforms legalising the activities of opposition parties (primarily the Senegalese Democratic Party led by Abdoulaye Wade) contributed in the long term to consolidating democratization processes, which was confirmed by the first peaceful transfer of power in 2000-2001. This seems to be one of the reasons why authoritarian rule has not been restored in Senegal, although various crises have taken place (mainly during Wade's presidency).

4. In general, the politics of constitutional amendment during the four Senegalese presidencies have followed different directions. Some of the constitutional reforms have had a positive impact on the emergence and consolidation of a democratic order, which have made Senegal stand out from many other Francophone African states. In turn, some of the other constitutional modifications analysed above have undermined this process. This all leads to the conclusion that the constitution is usually treated by governing camps as one of the available tools for strengthening their own political position. Hence, it can be said that the presidential politics of constitutional amendment has not been very coherent - regardless of which Senegalese politician was elected president and regardless of political circumstances (the existence of a democratic political competition). There is no coherence when it comes to a constitutional system of government which constantly oscillates between semi-presidentialism and presidentialism, although in the last two decades such modifications have not 
been very frequent (no such modifications occurred between 2001 and 2019). As regards regulations related to presidential succession and limits imposed on presidential terms, the amendments are always conditioned by the current political needs of the incumbent president (running for the next presidential term or transferring power to a person chosen by the head of state). In contrast, a much greater coherence of constitutional amendments may be identified in the field of the pluralization of political life, although in this case the letter of the constitution does not seem to have much in common with the practice of exercising power (cf. numerous attempts to undermine the status of anti-government opposition parties).

5. With this in mind, it can be concluded that the presidential politics of constitutional amendment in Senegal defies unequivocal assessment. This seems to be, to a greater or lesser extent, a typical feature of each of all four presidencies in the country. As it turns out, the existence of an authoritarian or democratic political order is not the factor that causes a qualitative difference in this case. Such regularity can be explained by the weakness of the institutional veto players. The procedure of constitutional changes has remained basically unchanged over the past six decades. From a constitutional point of view, the only veto player could be the legislature but its political composition (the body is practically constantly dominated by pro-presidential forces), precludes effective resistance to various presidential strategies in this field. In such circumstances, the effectiveness of presidential initiatives to modify constitutional provisions can be determined only by the activity of a veto player situated outside typical constitutional structures. Such a role may be played by society itself, which - as Wade's presidency proves - may force, through mass street protests, the head of state to step back from certain constitutional modifications.

Table 1. Constitutional Reforms in Senegal (1960-2019)

\begin{tabular}{|c|c|c|c|}
\hline \multirow[b]{2}{*}{$\begin{array}{l}\text { President of the } \\
\text { Republic }\end{array}$} & \multicolumn{3}{|c|}{ Types of constitutional reforms } \\
\hline & $\begin{array}{l}\text { Reforms introducing or } \\
\text { modifying the } \\
\text { constitutional system of } \\
\text { government }\end{array}$ & $\begin{array}{l}\text { Reforms concerning } \\
\text { presidential terms and } \\
\text { succession }\end{array}$ & $\begin{array}{l}\text { Reforms introducing or } \\
\text { strengthening } \\
\text { constitutional } \\
\text { guarantees of political } \\
\text { pluralism and political } \\
\text { participation }\end{array}$ \\
\hline $\begin{array}{l}\text { L.S. Senghor } \\
\text { (1960-1980) } \\
\text { Presidential } \\
\text { parliamentary majority } \\
\text {-Senegalese } \\
\text { Progressive Union/ } \\
\text { Socialist Party of } \\
\text { Senegal }\end{array}$ & $\begin{array}{c}1960 \text { - the adoption of } \\
\text { the first constitution of } \\
\text { independent Senegal } \\
1963 \text { - a new constitution } \\
\text { providing for a } \\
\text { presidential system of } \\
\text { government } \\
1967 \text { - the introduction } \\
\text { of the possibility to } \\
\text { dissolve parliament under }\end{array}$ & $\begin{array}{c}1963 \text { - a four-year } \\
\text { presidential term with no } \\
\text { restrictions as to re- } \\
\text { election } \\
1967 \text { - the extension of } \\
\text { the presidential term to } \\
\text { five years } \\
1970 \text { - the admissibility } \\
\text { of only one re-election } \\
1976 \text { - introduction of a }\end{array}$ & $\begin{array}{l}1976 \text { - the departure } \\
\text { from the one-party } \\
\text { system and legalization } \\
\text { of selected political } \\
\text { parties; the introduction } \\
\text { of a three-party system } \\
\text { with various ideological } \\
\text { currents (not determined } \\
\text { in the constitution itself) } \\
1978 \text { - the introduction }\end{array}$ \\
\hline
\end{tabular}

(continued) 
Table 1. Continued

\begin{tabular}{|c|c|c|c|}
\hline \multirow[b]{2}{*}{$\begin{array}{l}\text { President of the } \\
\text { Republic }\end{array}$} & \multicolumn{3}{|c|}{ Types of constitutional reforms } \\
\hline & $\begin{array}{l}\text { Reforms introducing or } \\
\text { modifying the } \\
\text { constitutional system of } \\
\text { government }\end{array}$ & $\begin{array}{l}\text { Reforms concerning } \\
\text { presidential terms and } \\
\text { succession }\end{array}$ & $\begin{array}{l}\text { Reforms introducing or } \\
\text { strengthening } \\
\text { constitutional } \\
\text { guarantees of political } \\
\text { pluralism and political } \\
\text { participation }\end{array}$ \\
\hline & $\begin{array}{l}\text { the existing presidential } \\
\text { system } \\
1970 \text { - the adoption of } \\
\text { the semi-presidential } \\
\text { system with a strong } \\
\text { position of the head of } \\
\text { state; the restoration of } \\
\text { the prime minister within } \\
\text { the executive power; } \\
\text { double political } \\
\text { responsibility of the } \\
\text { cabinet (to the president } \\
\text { and to the legislature) }\end{array}$ & $\begin{array}{l}\text { provision according to } \\
\text { which the presidency is } \\
\text { taken over by the prime } \\
\text { minister in the event of } \\
\text { the death or resignation } \\
\text { of the head of state until } \\
\text { the end of the normal } \\
\text { presidential term; the } \\
\text { repeal of the provision on } \\
\text { the admissibility of only } \\
\text { one re-election }\end{array}$ & $\begin{array}{l}\text { of a four-party system } \\
\text { with various ideological } \\
\text { currents (conservative, } \\
\text { liberal, socialist, } \\
\text { communist) }\end{array}$ \\
\hline $\begin{array}{l}\text { A. Diouf (1980-2000) } \\
\text { Presidential } \\
\text { parliamentary majority } \\
\text { - Socialist Party of } \\
\text { Senegal }\end{array}$ & $\begin{array}{l}1983 \text { - the transition } \\
\text { from the existing semi- } \\
\text { presidential system to a } \\
\text { presidential one } \\
1991 \text { - the adoption of } \\
\text { the semi-presidential } \\
\text { system; the restoration of } \\
\text { the prime minister within } \\
\text { the executive power; } \\
\text { double political } \\
\text { responsibility of the } \\
\text { cabinet (to the president } \\
\text { and to the parliament) }\end{array}$ & $\begin{array}{l}1991 \text { - the introduction } \\
\text { of the seven-year } \\
\text { presidential term; the re- } \\
\text { introduction of the } \\
\text { admissibility of only one } \\
\text { re-election } \\
1998 \text { - the repeal of the } \\
\text { provision on the } \\
\text { admissibility of only one } \\
\text { re-election }\end{array}$ & $\begin{array}{l}1981 \text { - the introduction } \\
\text { of an unrestricted multi- } \\
\text { party system without } \\
\text { restrictions on the } \\
\text { number of parties and } \\
\text { ideological currents }\end{array}$ \\
\hline $\begin{array}{l}\text { A. Wade (2000-2012) } \\
\text { 2000-2001 - anti- } \\
\text { presidential } \\
\text { parliamentary majority } \\
\text { (Socialist Party of } \\
\text { Senegal) 2001-2012 } \\
\text { - presidential } \\
\text { parliamentary majority } \\
\text { - Senegalese } \\
\text { Democratic Party }\end{array}$ & $\begin{array}{l}2001 \text { - the preservation } \\
\text { of the semi-presidential } \\
\text { system in a newly } \\
\text { introduced constitution } \\
\text { (semi-presidentialism } \\
\text { adopted in a more } \\
\text { balanced version } \\
\text {-stronger constitutional } \\
\text { position of the prime } \\
\text { minister and the cabinet, }\end{array}$ & $\begin{array}{l}2001 \text { - the introduction } \\
\text { of the five-year } \\
\text { presidential term, the } \\
\text { restoration of the } \\
\text { admissibility of only one } \\
\text { re-election (this provision } \\
\text { may be amended only by } \\
\text { means of a referendum) } \\
2008 \text { - the extension of } \\
\text { the presidential term to }\end{array}$ & $\begin{array}{c}2001 \text { - the } \\
\text { incorporation of } \\
\text { parliamentary opposition } \\
\text { rights into the new } \\
\text { constitution }\end{array}$ \\
\hline
\end{tabular}


Table 1. Continued

\begin{tabular}{|c|c|c|c|}
\hline \multirow[b]{2}{*}{$\begin{array}{l}\text { President of the } \\
\text { Republic }\end{array}$} & \multicolumn{3}{|c|}{ Types of constitutional reforms } \\
\hline & $\begin{array}{l}\text { Reforms introducing or } \\
\text { modifying the } \\
\text { constitutional system of } \\
\text { government }\end{array}$ & $\begin{array}{l}\text { Reforms concerning } \\
\text { presidential terms and } \\
\text { succession }\end{array}$ & $\begin{array}{l}\text { Reforms introducing or } \\
\text { strengthening } \\
\text { constitutional } \\
\text { guarantees of political } \\
\text { pluralism and political } \\
\text { participation }\end{array}$ \\
\hline & $\begin{array}{l}\text { but the government's } \\
\text { political responsibility to } \\
\text { the president remains) }\end{array}$ & $\begin{array}{l}\text { seven years } \\
2009 \text { - the creation of the } \\
\text { vice presidency } \\
2011 \text { - a failed attempt } \\
\text { to regulate presidential } \\
\text { succession by granting } \\
\text { the presidency to the } \\
\text { incumbent vice president, } \\
\text { as well as by lifting the } \\
\text { requirement to obtain an } \\
\text { absolute majority of votes } \\
\text { in the first round of } \\
\text { presidential elections }\end{array}$ & \\
\hline $\begin{array}{l}\text { M. Sall (since 2012) } \\
\text { Presidential } \\
\text { parliamentary majority } \\
\text { - Alliance for the } \\
\text { Republic }\end{array}$ & $\begin{array}{l}2019 \text { - an extensive } \\
\text { constitutional reform } \\
\text { aimed at introducing the } \\
\text { presidential system of } \\
\text { government (the abolition } \\
\text { of the post of prime } \\
\text { minister and the dual } \\
\text { structure of executive } \\
\text { power). }\end{array}$ & $\begin{array}{l}2012 \text { - the abolition of } \\
\text { the office of vice } \\
\text { president } \\
2016 \text { - the restoration of } \\
\text { a five-year presidential } \\
\text { term; the admissibility of } \\
\text { holding two consecutive } \\
\text { presidential mandates }\end{array}$ & $\begin{array}{l}2016 \text { - further } \\
\text { strengthening of the } \\
\text { constitutional position of } \\
\text { the parliamentary } \\
\text { opposition, including the } \\
\text { constitutional } \\
\text { recognition of the } \\
\text { opposition leader; } \\
\text { constitutional } \\
\text { guarantees for the } \\
\text { participation of } \\
\text { independent candidates } \\
\text { in elections. }\end{array}$ \\
\hline
\end{tabular}

Source: Author's own elaboration based on: Textes constitutionnels du Sénégal de 1959 à 2007' (Réunis et présentés par Ismailla Madior Fall) (2007) <http://www.assemblee-nationale.sn/documents/constitutionssenegal-59-07.pdf>; Fall (2017); Sy (2009); <http://www.jo.gouv.sn>.

\section{REFERENCES}

Alexander, Jr., A. S., 'The Ivory Coast Constitution: An Accelerator, Not a Brake' (1993) 3 The Journal of Modern African Studies 293-311 <http://dx.doi.org/10.1017/S0022278X00001713>. 
Baturo, A. and Elgie, R., 'Presidential Term Limits' in Baturo, A. and Elgie, R. (eds), The Politics of Presidential Term Limits (Oxford University Press 2019) 1-16.

Bermeo, N., 'On Democratic Backsliding' (2016) 1 Journal of Democracy 5-19.

Bininga, A.A.W., Les mutations constitutionnelles en Afrique noire francophone à partir des examples du Congo, du Bénin et du Sénégal (L'Harmattan Congo-Brazzaville 2019).

Cheibub, J. A., Presidentialism, Parliamentarism, and Democracy (Cambridge University Press 2007).

Chouli, L., 'The popular uprising in Burkina Faso and the Transition' (2015) 144 Review of African Political Economy 325-333, <https://doi.org/10.1080/03056244.2015.1026196>.

Conac, G., 'Semi-presidentialism in a francophone context' in Elgie, R., Moestrup S. (eds), Semi-presidentialism outside Europe. A comparative study (Routledge 2007) 78-91.

Desouches, C., Le Parti démocratique sénégalais. Une opposition légale en Afrique (Berger-Levrault 1983).

Diop, E. H. O., 'L'opposition sous la présidence d'Abdoulaye Wade. Entre regroupements, cooptation et repression' in Diop, M.C. (ed), Le Sénégal sous Abdoulaye Wade. Le Sopi à l'épreuve du pouvoir (CRES - Karthala 2013) 425-459.

Elgie, R., Semi-Presidentialism. Sub-Types and Democratic Performance (Oxford University Press 2011).

Fall, I. M., 'Constitutional Revisions, Democracy, and the State in Senegal' in Villalón, L.A. and Idrissa, R. (eds.), Democratic Struggle, Institutional Reform, and State Resilience in the African Sahel (Lexington Books 2020) 55-78.

Fall, I. M., Évolution constitutionnelle du Sénégal. De la veille de l'Indépendance aux elections de 2007 (Credila - Karthala - Crepos 2009).

Fall, I. M., La réforme constitutionnelle du 20 mars 2016 au Sénégal. La revision consolidante record, (L’Harmattan-Sénégal 2017).

Fall, I. M., Le pouvoir exécutif dans le constitutionnalisme des États d'Afrique (L'Harmattan 2008).

Fruhstorfer, A. and Hein, M., 'Institutional interests and the politics of constitutional amendment' (2021) OnlineFirst, International Political Science Review <https://doi.org/10.1177/0192512119871323>.

Fruhstorfer, A., 'Consistency in constitutional design and its effect on democracy' (2019) 6 Democratization 1028-1046 <https://doi.org/10.1080/13510347.2019.1590815>.

Gellar, S., Democracy in Senegal: Tocquevillian Analytics in Africa (Palgrave Macmillan 2005).

Heyl, C., 'Senegal (1970-2016): Presidential Term Limit Reforms Never Come Alone' in Baturo, A. R. and Elgie, R. (eds), The Politics of Presidential Term Limits (Oxford University Press 2019) 339-361.

Lavroff, D. G., La République du Sénégal (Librarie Générale de Droit et de Jurisprudence 1966).

Manning, P., Francophone Sub-Saharan Africa 1880-1995 (Cambridge University Press 1998).

Moestrup, S., 'Semi-presidentialism in Niger. Gridlock and democratic breakdown - learning from past mistakes' in Elgie, R. and Moestrup, S. (eds), Semi-presidentialism outside Europe. A comparative study, (Routledge 2007) 105-120.

Mueller, L., Political Protest In Contemporary Africa (Cambridge University Press 2018).

Müller, W. C., 'Governments and bureaucracies' in Caramani, D. (ed), Comparative Politics (Oxford University Press 2017) 136-154.

Nzouankeu, J. M., Les partis politiques sénégalais (Éditions Clairafrique 1984).

Osei, A., Party-Voter Linkage in Africa. Ghana and Senegal in Comparative Perspective (Springer 2012).

Prouzet, M., 'Les procédures de revision constitutionnelle' in Conac, G. (ed), Les institutions constitutionnelles des États d'Afrique Francophone et de la République Malgache (Économica 1979) 281320.

Shugart, M. S. and Carey, J. M., Presidents and Assemblies. Constitutional Design and Electoral Dynamics (Cambridge University Press 1992). 
Sidibé, D., Démocratie et alternance politique au Sénégal (L'Harmattan 2006).

Sy, S. M., Les régimes politiques sénégalais de l'independence à l'alternance politique 1960-2008 (IrokoKarhala-Crepos 2009).

Tsebelis, G., Veto Players. How Political Institutions Work (Russell Sage Foundation - Princeton University Press 2002).

Wiebusch, M. and Murray, C., 'Presidential Term Limits and the African Union' (2019) S1 Journal of African Law 131-160.

Zuccarelli, F., La vie politique sénégalaise (1940-1988) (Le Centre des Hautes Etudes sur l'Afrique et l'Asie Modernes 1988).

\section{LINKS:}

Au Sénégal, le Parlement adopte la réforme constitutionnelle (4 May 2019) <https://www.france24.com/fr/ 20190504-senegal-reforme-constitution-premier-ministre-suppression> accessed 30 August 2019.

Au Sénégal, le président Macky Sall va supprimer le poste de Premier ministre (6 April 2019) <https://www. france24.com/fr/20190406-senegal-macky-sall-premier-ministre> accessed 30 August 2019.

Ba, D. and O'Reilly, F., 'Senegal's Wade withdraws poll bill as protests rage' (23 June 2011) <https://www. reuters.com/article/us-senegal-protests/senegals-wade-withdraws-poll-bill-as-protests-rageidUSTRE75M6G020110623> accessed 30 August 2019.

Demarest, L., 'Staging a "revolution": the 2011-2012 electoral protests in Senegal', Centre for Research on Peace and Development Working Paper No. 20, 5 (2015) <https://soc.kuleuven.be/crpd/files/workingpapers/wp20.pdf> accessed 30 August 2019.

Democracy Index (2018) <https://www.eiu.com/topic/democracy-index> accessed 30 August 2019.

Democracy Index (2019) <https://www.eiu.com/topic/democracy-index> accessed 18 March 2020.

Le Sénégal supprime son Sénat (19 September 2012) <https://www.bbc.com/afrique/region/2012/09/ 120919_senegal_scraps_senate $>$ accessed 30 August 2019.

Loi constitutionnelle $\mathrm{n}^{\circ}$ 2008-66 du 21 octobre 2008, <http://www.jo.gouv.sn/spip.php?article7088> accessed 9 March 2020.

Loi constitutionnelle $\mathrm{n}^{\circ}$ 2009-22 du 19 juin 2009 instituant un poste de Vice-président de la République, <http://www.jo.gouv.sn/spip.php?article7529> accessed 31 August 2019.

Loi n 2001-03 du 22 janvier 2001 portant Constitution in 'Textes constitutionnels du Sénégal de 1959 à 2007’ (Réunis et présentés par Ismailla Madior Fall), (Credila 2007) <http://www.assemblee-nationale. sn/documents/constitutions-senegal-59-07.pdf> accessed 30 August 2019.

Loi n 59-003 du 24 janvier 1959 (Constitution de la République du Sénégal) in 'Textes constitutionnels du Sénégal de 1959 à 2007’ (Réunis et présentés par Ismaïla Madior Fall), (Credila 2007) <http://www. assemblee-nationale.sn/documents/constitutions-senegal-59-07.pdf> accessed 30 August 2019.

Loi n 60-045 A.N. du 26 août 1960 (Loi sénégalaise portant révision de la Constitution de la République du Sénégal) in 'Textes constitutionnels du Sénégal de 1959 à 2007' (Réunis et présentés par Ismaila Madior Fall), (Credila 2007), <http://www.assemblee-nationale.sn/documents/constitutions-senegal-59-07.pdf> accessed 30 August 2019.

Loi $\mathrm{n}^{\circ}$ 61-63 du 12 novembre 1961 portant révision de la Constitution in 'Textes constitutionnels du Sénégal de 1959 à 2007’ (Réunis et présentés par Ismaïla Madior Fall), (Credila 2007) <http://www. assemblee-nationale.sn/documents/constitutions-senegal-59-07.pdf> accessed 30 August 2019. 
Loi n ${ }^{\circ}$ 63-22 du 7 mars 1963 portant révision de la Constitution de la République du Sénégal in 'Textes constitutionnels du Sénégal de 1959 à 2007' (Réunis et présentés par Ismaïla Madior Fall), (Credila 2007) <http://www.assemblee-nationale.sn/documents/constitutions-senegal-59-07.pdf> accessed 30 August 2019.

Loi $n^{\circ}$ 67-32 du 20 juin 1967 portant révision constitutionnelle in 'Textes constitutionnels du Sénégal de 1959 à 2007' (Réunis et présentés par Ismailla Madior Fall), (Credila 2007) <http://www.assembleenationale.sn/documents/constitutions-senegal-59-07.pdf> accessed 30 August 2019.

Loi $\mathrm{n}^{\circ} 70-15$ du 26 février 1970 portant révision de la Constitution in 'Textes constitutionnels du Sénégal de 1959 à 2007' (Réunis et présentés par Ismaïla Madior Fall), (Credila 2007) <http://www.assem bleenationale.sn/documents/constitutions-senegal-59-07.pdf> accessed 30 August 2019.

Loi n ${ }^{\circ}$ 76-01 du 19 mars 1976 portant révision de la Constitution in: 'Textes constitutionnels du Sénégal de 1959 à 2007’ (Réunis et présentés par Ismaïla Madior Fall), (Credila 2007) <http://www.assem bleenationale.sn/documents/constitutions-senegal-59-07.pdf> accessed 30 August 2019.

Loi $\mathrm{n}^{\circ}$ 76-27 du 6 avril 1976 portant révision constitutionnelle in 'Textes constitutionnels du Sénégal de 1959 à 2007’ (Réunis et présentés par Ismaïla Madior Fall), (Credila 2007) <http://www.assembleetionale.sn/documents/constitutions-senegal-59-07.pdf> accessed 30 August 2019.

Loi n ${ }^{\circ} 78-60$ du 28 décembre 1978 modifiant la Constitution in 'Textes constitutionnels du Sénégal de 1959 à 2007' (Réunis et présentés par Ismailla Madior Fall), (Credila 2007) <http://www.assemblee-natio nale. sn/documents/constitutions-senegal-59-07.pdf> accessed 30 August 2019.

Loi $\mathrm{n}^{\circ}$ 81-16 du 6 mai 1981 portant révision constitutionnelle in 'Textes constitutionnels du Sénégal de 1959 à 2007' (Réunis et présentés par Ismailla Madior Fall), (Credila 2007) <http://www.assemblee-natio nale.sn/documents/constitutions-senegal-59-07.pdf> accessed 30 August 2019.

Loi n ${ }^{\circ} 83-55$ du $1^{\text {er }}$ mai 1983 portant révision de la Constitution in 'Textes constitutionnels du Sénégal de 1959 à 2007' (Réunis et présentés par Ismaïla Madior Fall), (Credila 2007) <http://www.assem bleenationale.sn/documents/constitutions-senegal-59-07.pdf> accessed 30 August 2019.

Loi ${ }^{\circ}$ 91-25 du 5 avril 1991 portant révision de la Constitution in 'Textes constitutionnels du Sénégal de 1959 à 2007’ (Réunis et présentés par Ismaïla Madior Fall), (Credila 2007) <http://www.assembleenationale.sn/documents/constitutions-senegal-59-07.pdf> accessed 30 August 2019.

McConnell, T., 'People power in Senegal' (24 June 2011) <https://www.pri.org/stories/2011-06-24/peoplepower-senegal> accessed 30 August 2019.

Senegal's president can run for third term, court rules (30 January 2012) <https://www.theguardian.com/ world/2012/jan/30/senegal-president-run-third-term> accessed 11 August 2020.

Soares, U., 'Sénégal: les économies liées à la suppression du Sénat financeront les victimes des inondations' (19 September 2012) <http://www.rfi.fr/afrique/20120919-senegal-suppression-senat-profit-victimesinondations $>$ accessed 30 August 2019.

Wade drops contested electoral reform (23 June 2011) <http://en.rfi.fr/africa/20110623-wade-dropscontested-electoral-reform> accessed 30 August 2019. 